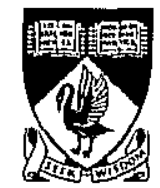

IMMIGRANTS' LANGUAGE SKILLS AND VISA CATEGORY

by

\author{
Barry R. Chiswick \\ Yew Liang Lee \\ and \\ Paul W. Miller
}

DISCUSSION PAPER 02.05

DEPARTMENT OF ECONOMICS

THE UNIVERSITY OF WESTERN AUSTRALIA

35 STIRLING HIGHWAY

CRAWLEY, WA 6009

AUSTRALIA 
Preliminary

Not for citation without permission of an author.

\title{
IMMIGRANTS' LANGUAGE SKILLS \\ AND VISA CATEGORY
}

\author{
by
}

\author{
Barry R. Chiswick \\ Department of Economics \\ University of Illinois at Chicago \\ Yew Liang Lee \\ Department of Economics \\ University of Western Australia \\ Paul W. Miller* \\ Department of Economics \\ University of Western Australia
}

Key Words: Immigration, Language Proficiency, Visa Categories, Australia

JEL Codes: J61, J24, J18

* Miller acknowledges financial assistance from the Australian Research Council. 
March 2002

\title{
IMMIGRANTS' LANGUAGE SKILLS
}

AND VISA CATEGORY

\begin{abstract}
This paper is concerned with the determinants of English language proficiency among immigrants in a longitudinal survey for Australia. It focuses on both visa category and variables derived from an economic model of the determinants of destination language proficiency among immigrants.

Skills tested and economic immigrants have the greatest proficiency shortly after immigration, followed by family-based visa recipients, with refugees having the lowest proficiency. These differences disappear by $3 \frac{1}{2}$ years after immigration for speaking skills, but they persist for reading and writing skills. The variables generated from the model of destination language proficiency are in part predictions of visa category and are more important statistically for explaining proficiency. The effects of some variables on language skills increase with duration in these longitudinal data. In particular, the efficiency variable, age, and gender, which may be reflecting differences in labor market attachment, increase in importance over time. (146 words).
\end{abstract}


March 2002

\section{IMMIGRANTS' LANGUAGE SKILLS AND VISA CATEGORY}

\section{Introduction}

Language skills matter for immigrant adjustment. The effects of fluency in the destination language on earnings are around 17 percent in the United States, 12 percent in Canada and Israel, and between 5 and 10 percent in Australia (Chiswick and Miller (1995)). The clear earnings advantages to the possession of destination language skills has sparked a large volume of research into the determinants of these skills (see, for example, Chiswick and Miller (1995)(1996)(1999) for Australia, Chiswick and Miller (1994)(2001) for Canada, Dustman (1994) for Germany, Chiswick (1998) for Israel, and Chiswick and Miller (1992a)(1998) for the US).

It has been demonstrated in studies for these countries in different time periods that immigration at an older age is associated with lower proficiency in the destination language, while destination language skills are greater the longer the duration in the host country and among the better educated. Language skills have also been shown to vary with the "linguistic distance" between the immigrant's mother tongue and the destination language, with the degree of favorable selectivity in migration and the propensity for return migration, with exposure to the destination language in the origin and with refugee status. The characteristics of the immigrant's region of residence also impact on their destination language skills, with greater access to the immigrant's mother tongue in the region in which the immigrant lives being associated with poorer destination language skills. Moreover, the characteristics of one's family matters as proficiency has been shown to vary systematically with marital status and among those married with the language proficiency of one's spouse and the presence of children in the family (Chiswick and Miller 1998, 2001, 2002b). 
The findings from research into immigrants' language skills have implications for public policy. The foreign born in any country will be more proficient in the destination language if the immigration policy focuses on younger immigrants, those with higher levels of schooling, and individuals exposed to the destination language in the country of origin. Many of these characteristics are explicitly incorporated into the immigration policy of some Western countries. For example, in Australia selection into the skilled migration categories is based on a points system, where points are awarded for age, skills (mainly educational qualifications and occupationspecific training), English language proficiency and pre-immigration employment experience, among other factors. Dominant or destination language skills among immigrants are therefore expected to vary with visa category.

This study examines the impact of visa category on the English language skills of recent immigrants to Australia. It seeks to understand the extent to which immigration selection criteria have an impact on language skills, and also the extent to which this impact is over-and-above that which is attributable to the age, skill and behavioral factors that have been the focus of previous research. By following a cohort of recent arrivals for the first few years of residence in Australia, an assessment can be made of whether any links between visa category and English-speaking skills are temporary or permanent. A temporary relationship might arise where visa category simply picks up the initial selection for some visas partly on the basis of English skills. A permanent relationship might develop where visa category captures influences that contribute to immigrant adjustment, including proficiency in English, over and above the factors that are points tested (and which can be included in the models estimated) within particular visa categories. As information on immigrant 
visa category is rarely available for the study of dominant language skills, this analysis is a major contribution to the literature.

The structure of the paper is as follows. Section II reviews salient features of the Longitudinal Survey of Immigrants to Australia that provides the basis for this study. Section III outlines a model where the incentives for the acquisition of dominant language skills are related to variables for efficiency in the learning of languages, the exposure of an immigrant to the dominant language both pre- and postmigration, and the economic costs and benefits associated with bilingualism for those whose mother tongue is not the lingua franca of the destination country. To introduce the basic patterns in the data, cross-tabulations of English speaking, reading and writing skills by visa category are presented and discussed in Section IV. Section V contains estimates of the multivariate model developed in Section II. Concluding comments are provided in Section VI.

\section{The Longitudinal Survey of Immigrants to Australia}

The analyses reported below are based on the Longitudinal Survey of Immigrants to Australia (LSIA), a longitudinal study of immigrants who received their visas before entry into Australia. The population represented in the sample is all Principal Applicants, aged 15 years and over, who arrived in Australia as offshore visaed immigrants in the two-year period of September 1993 to August $1995^{1}$

Immigrants were interviewed three times in this survey. The first interview took place approximately five or six months after arrival, the second interview one year later and the third interview a further two years later. The first, second and third

\footnotetext{
${ }^{1}$ The Principal Applicant is the person upon whom the approval to immigrate was based. Excluded from the scope of the survey are New Zealand citizens for whom there is unrestricted entry into Australia and those granted a visa while resident in Australia.
} 
waves of interviews commenced in March 1994, March 1995 and March 1997, respectively.

Principal Applicant immigrants selected for interview were those who settled in the eight State and Territory capital cities (including major urban centers close to capital cities such as Newcastle and Wollongong), as well as Cairns. Only 4 to 5 percent of the total of Principal Applicant immigrants are excluded from the coverage of the survey because they live outside of these areas. The final LSIA sample was 5192 Principal Applicant arrivals. This represents about seven percent of all Principal Applicants who arrived in the two-year survey period. The population from which the sample was selected at random was stratified according to visa eligibility category ${ }^{2}$ and also by about fifty regions or countries of birth.

A feature of the sampling frame for the LSIA is that Principal Applicants in smaller States and Territories were over-sampled. Weights are available to adjust for this. These estimation weights were modified to account for sample attrition between the first and third waves of the survey. ${ }^{3}$ As noted by Murphy (1997, p.66), the LSIA data should be used in weighted form so that the sample reflects the total population of immigrants arriving in the reference period. All analyses in this study use relevant estimation weights.

The LSIA contains a considerable amount of information on language skills. In each wave of interviews, individuals were required to provide details on the languages they speak well, the main languages spoken at home in Australia, and the

2 The five main visa categories are Preferential Family, Concessional Family, Business Skills and Employer Nomination, Independent, and Humanitarian (refugees).

${ }^{3} 723$ Principal Applicants were lost from the sample by the time of the second wave of interviews (attrition rate of 13.9 percent) and a further 717 by the time of the third wave of interviews (i.e., total attrition of 1440 or 27.7 percent). These attrition rates are reasonably high, and arise for a variety of reasons. For example, analysis of the wave 1-wave 3 attrition shows that 11 percent of the wave 1 participants could not be tracked to wave 3, 4 percent refused to be interviewed, 11 percent were overseas (temporarily or permanently) and 2 percent were not interviewed for other reasons (see Osborne (1999)). 
languages they speak the best. Individuals whose best spoken language was not English (generally individuals from non-English speaking countries) had to self-assess their English speaking, reading, and writing skills.

\section{A Model of Language Skills}

Chiswick and Miller (1992a)(1994)(1995)(1996)(1998) and Espenshade and Fu (1997), among others, have developed empirically tractable models of the propensity for an immigrant to acquire dominant language skills. The variables included in these models can be categorized into three broad sets of factors, namely economic incentives, efficiency in language acquisition, and exposure to the dominant language prior to and after migration. Thus, the propensity for an immigrant to acquire dominant language skills is modeled as:

(1) $\quad$ LANG $=f($ economic incentives, efficiency, exposure).

Economic incentives for the acquisition of language skills depend on the labor market (i.e., the wage, training and employment increments) and consumption (i.e., lower search costs for favorable prices and higher quality goods and services) benefits expected to be associated with dominant language proficiency. It has proven difficult to find measurable counterparts to these variables. In the current study visa category could provide one proxy for the labor market benefits, with immigrants who enter Australia under Business, Independent and, to a lesser extent, Consessional Family visas, being expected to have greater labor market involvement and hence greater returns from any investments that are productive in the labor market than immigrants 
in other visa categories. ${ }^{4}$

The expected length of time over which the wage and other employment and consumption gains are to be realized is also likely to be an important factor. Information on whether immigrants expected to leave Australia permanently at some future date can be used to capture this effect. Birthplace can also be used as a measure of the incidence of return migration, since origins differ in the extent of permanent and sojourner migration. Finally, the geographic distance of the country of origin from the destination is also relevant as greater geographic distance is expected to be associated with a lesser expectation of return migration and hence a greater incentive to invest in destination specific skills, including language skills.

Efficiency refers to the extent to which a given amount of destination language exposure produces language proficiency. It has been shown in numerous studies that proficiency is enhanced by a higher level of education and by migration while young (see Long (1990), Service and Craik (1993) on the age effects in language attainment). Consistent with this assessment, both age and educational attainment are incorporated into the assessments for the points-tested visa categories in Australia on the grounds that they are related to post-migration success.

"Linguistic distance", that is, the extent of the difference between the origin and destination language, is also a measure of efficiency. An index of "linguistic distance" based on the degree of difficulty that Americans who are native English speakers have learning foreign languages has been developed by Chiswick and Miller (1998). It is developed from a set of language learning scores (LS) presented in HartGonzalez and Lindemann (1993). A low value of the score is indicative of a high

\footnotetext{
${ }^{4}$ These visa categories are points tested for post-migration economic success. The findings reported by Miller (1999), however, where migration categories other than Humanitarian were shown not to be important to labor market outcomes once account was taken of the immigrants' productivity-related endowments, suggests that productivity-related variables such as educational attainment provide a superior proxy of labor market benefits.
} 
degree of difficulty (e.g., Cantonese $\mathrm{LS}=1.25$ ) and a high value is indicative of a low degree of difficulty (e.g., Dutch LS $=2.75$ ). In the empirical application, linguistic distance is measured as the reciprocal of the language score, that is, $L D=1 / \mathrm{LS}$. Thus, a higher value for LD means a greater distance between English and the origin language.

Exposure has three dimensions. These are: exposure prior to migration, time units of exposure in the destination country, and the intensity of exposure per unit of time in the destination ${ }^{5}$.

One measure of pre-immigration exposure is the extent of cross country/culture contact (not necessarily with Australians) in the country of origin. The hypothesis is that immigrants from countries where there is a lot of contact of this nature would be more likely to have been exposed to English, or at least have a relatively favorable disposition towards other cultures that may be associated with a greater preparedness to learn English.

A second variable is whether the immigrant visited Australia prior to migrating. Visits to Australia prior to migration could reflect two factors. The immigrant would be exposed to English during such visits. Moreover, the visits could be indicative of a greater degree of planning for the migration, and hence a lesser likelihood of return migration. A greater degree of planning would generally include greater attention to the language skills required in the destination. Accordingly, it is expected that immigrants who visited Australia prior to migrating would have English skills superior to the skills of those who did not visit Australia.

\footnotetext{
${ }^{5}$ The number of years since migration provides a measure of time units of exposure in the destination country. While this variable plays a key role in cross-sectional studies, it is not a direct consideration in the study of language skills in a single arrival cohort since duration is the same for all observations.
} 
The intensity of exposure per unit of time in the destination is more complex. It will depend on the characteristics of the person's home and location. The home environment is measured in most analyses through variables for the number and ages of children, and for the birthplace or language skills of the spouse. In the LSIA there is information both on the family structure and on whether children live with their parents. Moreover, the survey contains details on whether other people who were part of the "migrating unit" live with the respondent. Hence the following variables may be included in the estimating equation that corresponds to the language model: whether a spouse who was part of the migrating unit is present in the household (MUS); whether a spouse who was not part of the migrating unit is present in the household (OS); whether there are children in the household (KIDS); whether other relatives who gained approval to migrate to Australia as part of the Principal Applicant's migration application are present in the household (MUR); whether other relatives are present in the household (OR).

The information on the immigrant's living arrangements can be complemented with information on the main reason the immigrant chose his/her State of initial settlement. Where "family/friends" is the main reason for the choice of location, it is expected that the immigrant will be more likely to have access to an ethnic network. The availability of this ethnic network can reduce the exposure to, and practice in using, English.

The characteristics of the person's location have been typically captured by a "minority-language concentration" variable. This is generally measured as the percentage of individuals living in the immigrant's region of residence that speaks the same minority language as the immigrant. A similar concentration variable can be constructed using the birthplace characteristics of the region of residence, and this is 
the approach followed in this study. As there are obvious links between birthplace and language, especially when disaggregated birthplace data are used (around 50 birthplaces are used in the current analysis) this should not be viewed as a limitation. ${ }^{6}$

In a region where a high percentage of individuals are from the same birthplace, and hence many will speak the same minority language as the immigrant, the costs of not knowing the dominant language, or the benefits of learning the dominant language, are presumably decreased. These effects arise from the ability to communicate in consumer, labor market and social activities in the immigrant's mother tongue. Moreover, since second language skills improve with experience using the language, improvements in English language skills are retarded by using the mother tongue.

The empirical counterpart to equation (1) used in this research is:

(2) $\mathrm{LANG}=\mathrm{f}$ (visa category, age, education, gender, birthplace, preparation for migration, expected duration in destination, family structure, prevalence of origin language in region of residence, linguistic distance, distance of origin country).

All variables are defined in Appendix A. This appendix also contains means and standard deviations for the variables. The sample is restricted to Principal Applicants aged 15 to 64 years at immigration and, given the interest in the development of English language skills, excludes immigrants from the main English speaking developed countries. ${ }^{7}$

\footnotetext{
${ }^{6}$ Where individuals do not report speaking a language other than English, a minority language concentration variable is often constructed using details on place of birth, adding to the similarity of the two variables.

${ }^{7}$ The main English speaking countries excluded from in this analysis are the UK, and Ireland, Canada, South Africa and the US. These restrictions are generally imposed in studies of dominant language proficiency to permit a focus on the group for whom the decision concerning the acquisition of dominant language skills is most relevant.
} 


\section{Visa Category and Language Skills}

Table 1 lists information on English speaking skills by visa category in wave 1, that is, around 6 months after arrival in Australia. The categories of English skills used in the Table distinguish five levels, namely (i) speaks English only or, if a language other than English is spoken, English is spoken best (referred to as "English best"); speaks a language other than English best and speaks English (ii) very well; (iii) well, (iv) not well; (v) not at all.

According to the information in Table 1, 12 percent of the immigrants from other than the main English-speaking countries speak English the best (see the final column). Fourteen percent of this group of immigrants speak a language other than English best and speak English very well, while 28 percent speak English well. Onethird of the immigrants do not speak English well, while 14 percent report that they do not speak English at all.

The distribution of immigrants across the English skill categories at wave one is not neutral with respect to visa category. It is apparent that skill-based immigrants (i.e., those with Business Skills/Employer Nomination Scheme, Concessional Family $^{8}$, and Independent visas) have bigher English language proficiency than immigrants who have entered Australia under either Preferential Family or Humanitarian (refugee) visas. This is to be expected since the former visa categories are based on a points system, where points are awarded, in part, for English language proficiency (see Appendix A). In particular, 22 percent of individuals with Independent visas speak English the best and a further 28 percent speak English very well. In the case of Business Skills/Employer Nomination Scheme visaed immigrants,

\footnotetext{
8 The Concessional Family category lies in between the family-based and skill-based migration category, with potential migrants being assessed on both skills and more distant family relationships.
} 
the numbers in the top two categories of English speaking skills are 19 percent (English the best) and 22 percent (speak English very well). Individuals under the Concessional Family visa category tend to fall in the upper language skill levels (38 percent in the top two categories). The majority of migrants with Preferential Family visas have English speaking skills in the lower levels, only 18 percent are in the top two categories and 51 percent speak English "not well" or "not at all.". There are very high proportions of individuals under the Humanitarian visa category who selfassessed their English speaking skills as "not well" (56 percent) and "not at all" (22 percent), for a total of 76 percent in the two lowest categories.

Tables 2 and 3 provide information on, respectively, English reading and writing skills by visa category at wave one. The information gathered in the survey enables the separation of individuals into those who speak English the best, those who do not speak English at all, and those who possess different levels of English reading (and writing) skills. In principle, individuals who speak English well need not necessarily read or write English well, and vice versa. However, a cross-tabulation of speaking proficiency by reading skills shows that more than 98 percent of individuals who speak English "very well" have reading skills rated as "well" and above. ${ }^{9}$ About 77 percent of those who do not speak English well also do not write well.

In all cases, except individuals with Humanitarian visas, the majority self-rate their reading skills as "well" and above. If the first three skill levels ("English best", "very well" and "well") combined are viewed as proficient in English reading, the proficiency rates range from 96 percent for immigrants with Independent visas to only 36 percent for immigrants in the Humanitarian category. Just like in Table 1,

\footnotetext{
${ }^{9}$ Information on English speaking skills by English reading and writing skills is available from the authors.
} 
immigrants whose visas are skill-based tend to read English "well" and above compared to other immigrants.

The results presented in Table 3 reveal that large proportions of individuals under the Preferential Family, Concessional Family, Business Skills/Employer Nomination Scheme and Independent visa categories self-assessed their writing skill levels as "well" or better. Viewing the first three categories ("English best", "very well" and "well") combined as representing writing proficiency, this ranges from 91 percent for the Independent visa category to only 25 percent for immigrants who entered Australia under the Humanitarian program. It is noted that the rate of English writing proficiency is up to 10 percentage points lower in each visa category compared to the rate of English reading proficiency. In turn, the rates of writing proficiency are comparable to the rates of speaking proficiency evident from Table 1. Thus reading seems to be the easiest of the three skills to master.

Tables 1-3 clearly show that English speaking, reading and writing skills vary across the visa categories, and are considerably higher among skill-based immigrants.

\section{Regression Results}

The multivariate regression approach to estimation is as follows. First, a model that includes only visa category is estimated. The estimated coefficients on the visa category variables in this restricted regression will show the extent to which migration policy is effective in terms of selecting immigrants who have superior language skills. Then variables for educational attainment, age at migration, gender, the main reason for choosing the State settled, family structure, and a number of variables that are related to birthplace are entered into the estimating equation. The birthplace-related variables include the distance between the origin country and the place of residence in Australia, linguistic distance, minority language (birthplace) 
concentration, the cross country/culture contact in the former home country, the expectation of return migration and whether the origin country was a former British colony. This estimating equation will show whether visa category has an impact on English-speaking proficiency over and above the effects associated with the variables that are usually included in models of dominant language skills (see Miller (1999) for a similar approach to the assessment of the impact of migration category on labor market outcomes). Finally, for comparative purposes, the language equation is recomputed without the visa variables.

Table 4 lists results for models of English-speaking skills estimated for a sample pooled across males and females. ${ }^{10}$ The dependent variable $\left(L A N G_{i}\right)$ in this first set of analyses is a binary variable that records the immigrant's English speaking skills. Individuals who speak English the best (or English is the only language they speak), or where a language other than English is spoken, English is spoken "very well" or "well", are classified as proficient in this section of the study. They take the value of unity in the dichotomous language variable, $L A N G_{i}$, while those less proficient are coded zero.

To specify the relationship between the binary dependent variable $\left(L A N G_{i}\right)$ and the set of explanatory variables described above, a probit model is used. Under this model, the probability of immigrant $\mathrm{i}$ being proficient in English is assumed to be given by:

$$
\operatorname{Pr}\left(L A N G_{i}=1\right)=\Phi\left(\beta X_{i}\right)
$$

\footnotetext{
${ }^{10}$ Appendix B contains estimates obtained from the separate samples of males and females. Inspection of these results shows there is little advantage to the study of English skills of the separate samples of male and female principal applicants over study of the pooled sample. There are differences, and interesting correlations of the measured and unmeasured determinants, between the Principal Applicants and their spouses who accompany them (see Chiswick and Miller, 2002b).
} 
where $L A N G_{i}$ is the dichotomous language variable, $\Phi$ is the standard normal cumulative distribution function, and $X$ is a vector of explanatory variables. $\beta$ is the set of parameters that capture the impact of changes in $X$ on the probability of being proficient.

Marginal effects may be computed from the probit model as follows. Let $X_{i k}$ be the $\mathrm{k}^{\text {th }}$ element of the vector $X_{i}$ and let $\beta_{k}$ be the $\mathrm{k}^{\text {th }}$ element of the parameter vector $\beta$. Then:

(4) $\frac{\delta}{\delta X_{i k}} \Phi\left(\beta X_{i}\right)=\phi\left(\beta X_{i}\right) \beta_{k}$,

where $\phi$ is the standard normal density function and $\phi\left(\beta X_{i}\right) \beta_{k}$ is the change in the probability in the probit model. A useful way of evaluating this is to do so at the value of the probit index $\beta X$ that solves the equation $\beta X=\Phi^{-1}(\overline{L A N G})$, where $\overline{L A N G}$ is the mean rate of proficiency for the sample and $\Phi^{-1}$ is the inverse normal cumulative distribution function. With a mean proficiency of 0.504 the appropriate value of $\phi(\beta X)$ is 0.399 . The partial effects obtained in this manner can be multiplied by 100 to give percentage point impacts. ${ }^{11}$

The specification considered in Table 4, column (1) contains only information on visa categories. It is apparent that these visa variables must summarize a considerable volume of information on the immigrants. The prediction success rate, which serves as one useful summary measure of the fit of the model, is 66.3 percent. Using the mean proficiency of 0.504 , the prediction success rate under random

\footnotetext{
${ }^{11}$ See Amemiya (1981, p.1488) for relevant discussion.
} 
assignment is 50.0 percent. $^{12}$ In other words, the model based on just four explanatory variables improves the prediction success rate by 16 percentage points, or by one-third of the prediction error. The coefficients on the visa category variables are quite informative: the negative coefficients indicate that the mean level of English proficiency is highest in the Independent group. It is clear that the coefficients on the other visa category variables become more negative as skills or skill-related characteristics diminish. Hence the ranking in terms of English speaking skills (from most proficient to least proficient) is Independent, Business Skills, Concessional Family, Preferential Family, Humanitarian. This is similar to the ranking of visa categories in terms of other human capital skills. ${ }^{13}$

In Table 4, column (2) variables for age at migration, education, gender, main reason for choosing State settled, the family structure and the behavioral variables that are related to birthplace groups are added to the estimating equation of column (1). Out of the 18 variables added, 14 are statistically significant at the 10 percent level or better. The goodness of fit, as compared to that in column (1), improves as indicated by a higher prediction success rate ( 79.0 percent vs. 66.3 percent). That is, these variables explain about 40 percent of the remaining prediction error (i.e., 12.7 points out of 33.7 points).

The estimated coefficients on these additional variables are mostly consistent with those reported in the literature (e.g., Chiswick and Miller (1995)), and only brief comments are provided. The estimates show that English-speaking proficiency decreases with age at migration, with each extra year of age at migration being

\footnotetext{
${ }^{12}$ Under random assignment using the mean proficiency $(p)$, the prediction success rate is computed as $\left[p^{2}+(1-p)^{2}\right] * 100 \%$.

${ }^{13}$ The mean educational attainment for individuals under the Independent visa category is 16.63 years. The respective means for individuals under the Business Skills, Concessional Family, Preferential Family and Humanitarian categories are 15.48 years, 15.57 years, 13.23 years and 12.55 years.
} 
associated with about a 0.6 percentage point reduction in the level of English speaking proficiency. ${ }^{14}$ This partial effect is quite modest compared to that associated with educational attainment, where each additional year of education is associated with an increase in the level of English speaking proficiency of 7.3 percentage points. The effect of one extra year of schooling is equivalent to about 12 fewer years of age at migration.

One of the most pronounced impacts on English-speaking skills is associated with those who were originally from former British colonies. These immigrants are much more likely to be proficient in English, the partial effect showing that they have a rate of proficiency in English that is 55 percentage points higher than that of other immigrants. Clearly exposure to English in the country of origin matters, a conclusion which is reinforced by the statistical significance and positive coefficients on the variables for whether there was cross country/culture contact in the former home country and for whether the immigrant had visited Australia prior to the migration.

Female principal applicant immigrants in wave one are less proficient than their male counterparts by 6.5 percentage points, or nearly the equivalent of one year of schooling. This small gender difference is itself of interest given the lower labor supply of women. ${ }^{15}$

Family and friends are also important determinants of English-speaking proficiency, as shown by the statistical significance of most family variables, including whether the main reason for choosing the State settled was family/friends. The presence of family/friends in Australia, whether part of the migrating unit or otherwise, is associated with lesser English-speaking proficiency.

\footnotetext{
${ }^{14}$ All partial effects in this section are computed as $\left(0.399 * \hat{\beta}_{\Phi} * 100\right)$ where $\hat{\beta}_{\Phi}$ is an estimate of the coefficient from the probit model, and the 0.399 is computed as described in the text.

${ }^{15}$ For a fuller discussion of gender differences using these data, see Chiswick, Lee and Miller (2002b).
} 
A further variable that is associated with a significant reduction in the English speaking skills of Principal Applicants is where there is an expectation of leaving Australia. Principal Applicants in this category are 15 percentage points less likely to be proficient in English.

The birthplace concentration variable is at the margin of significance. The coefficient of -0.008 implies that each extra percent of the population in the postcode area of residence that is from the same country of birth as the Principal Applicant is associated with about one-third a percentage point reduction in English speaking skills (i.e., $-0.008 \times 0.399 \times 100=0.32$ ). This finding is similar to that reported in the literature on the role of ethnic enclaves in immigrant adjustment (e.g., Chiswick and Miller (1995)), revealing that at least during the initial phases of the immigrant settlement, residence in ethnic enclaves is associated with slower adjustment, or that the less proficient new immigrants settle in areas where others speak their origin language.

The coefficient on the linguistic distance variable is negative. The negative coefficient implies that, as hypothesised in Section II, immigrants whose mother tongues are linguistically distant from English (e.g., Korean with a linguistic score of 1.0) are less likely to be proficient in spoken English than immigrants whose mother tongues are linguistically closer to English (e.g., French with a linguistic score of 2.5).

The inclusion of these additional variables reduces the coefficients on the visa category variables by between one-half and two-thirds, that is, they reduce the differences in language skills among the visa categories. In terms of absolute values, the largest impact is on the Preferential Family visa group (75 percent) and the least impact is on the Concessional Family visa group (47 percent). This result is similar to that reported by Miller (1999). There it is shown that the immigrants subject to tests 
relating to their employability to gain entry into Australia have mean unemployment rates lower than those experienced by other categories of immigrants, leading to the conclusion that the migration points tests in Australia offer useful screens. However, when account was taken of variables reflecting the characteristics of the immigrants (e.g., the age, qualifications, and English skills factors which enter into migration selection in the Australia points system) the unemployment rate differential between the immigrants who were sponsored by family and hence not subject to points testing, and those who were subject to tests relating to their employability, were not statistically significant. This led to the conclusion (Miller (1999, p.195)) that "the unemployment rate differentials across migration categories appear to reflect the underlying characteristics of the immigrants rather than immigrant category per se", and these characteristics are well summarized by the visa categories. ${ }^{16}$ Similar findings are reported by Wooden (1990) and Chiswick and Miller (1992b).

The model presented in Table 4, column (2) was re-estimated omitting the visa category variables. Results are listed in column Table 4, column (3). This change has little impact on either the coefficients on individual variables, or the overall fit of the model. For example, the prediction success rate declines by only around one-half a percentage point, from 79.0 percent to 78.4 percent. This reinforces the conclusion that the visa categories are in large part summaries of the information contained in the other variables included in the model.

Finally, it is noted that the models were also estimated including country of birth fixed effects. With Southern Europe as the benchmark six of the ten birthplace coefficients were statistically significant in the estimation corresponding to the

\footnotetext{
${ }^{16}$ Hurnanitarian immigrants were, however, distinguished by sizeable unemployment rate differentials, even when account was taken of productivity-related variables.
} 
specification listed in column (2) (results not reported here). Their inclusion, however, had minimal effect on either the overall fit of the model (the prediction success rate increased by just under two percentage points from 79.0 percent to 80.8 percent) or on the individual coefficient estimates. This suggests that the behavioral variables constructed in part using the birthplace information are able to capture very much the same information in relation to the language practice among immigrants as the birthplace dummy variables. Unlike dichotomous variables for country of birth, the constructed variables are open to behavioral interpretations, and they provide for greater understanding of the factors affecting language practice among immigrants (see also Chiswick and Miller (2001)).

In the remainder of this section, the models presented in Table 4 are reestimated using data from waves two and three of the survey. The aim is to see how the coefficients on the explanatory variables, particularly those for visa category, alter with duration on Australia. As the overwhelming majority of the variables are time invariant, there is little advantage in terms of behavioral modelling to attempting to estimate panel data models of changes in English skills. ${ }^{17}$

Table 5 presents the estimates from the wave two and wave three data. As the focus of the study is on visa category, for simplicity of exposition, only the estimates for visa category, the education and age at migration variables that enter into the assessment for the points-tested visa categories and the gender variable where the estimated coefficients appear to provide considerable insights into the motivation for the development of English skills, are presented and discussed. ${ }^{18}$

\footnotetext{
${ }^{17}$ The following sets of variables may vary with time: location of residence (and the birthplace concentration variable based on this), family structure, ethnic agencies contact, and emigration expectation. All other variables are time invariant in this sample.

${ }^{18}$ The full sets of estimates are available from the authors.
} 
The proportion proficient in English in wave one (five to six months after migration) was 50.4 percent. For wave two (about 18 months after migration) the proportion proficient was 59.6 percent. For wave three (about 3.5 years after migration) the proficiency rate was 65.5 percent, a growth of 15.1 percentage points. These proficiency rates are computed on successively smaller samples due to sample attrition. The mean rates of proficiency in waves one and two for the sample used in wave three are 49.0 percent and 59.6 percent, respectively, for an increase in proficiency among the "stayers" of 16.5 percentage points. These slightly higher rates compared to those discussed in the text indicate that attrition (see footnote 3) is less intense among those who cannot speak English. However, the similarity of the changes in proficiency among all sample members and among "stayers" indicates that the growth in English proficiency of about 15 percentage points over the course of the three interviews is largely due to the development of language skills rather than being a product of sample selection bias.

Comparison of the partial effects in the models can be undertaken when these are evaluated at the probit index that gives the mean proficiency rate for each sample. ${ }^{19}$ Alternatively, the effects can be compared when multiplied by the same factor (0.399) as used for the wave one data. The latter approach will be followed to provide a degree of standardization in the comparisons. This means also that a direct comparison of the coefficients in the probit equations will be informative.

The main feature of the comparison across waves is that the effects associated with visa categories tend to decrease with duration of residence in Australia. That is, the differences in the effects on language skills of visa category decrease as the analysis moves from wave one to wave two to wave three. Consider the coefficients

\footnotetext{
${ }^{19}$ For wave two the appropriate adjustment factor 0.387 ; for wave three it is 0.369 .
} 
associated with the Humanitarian visa category, compared to the benchmark, the Independent migrant group. This was -0.796 in wave one, -0.407 in wave two and a statistically insignificant -0.179 in wave three. Similarly, the coefficient for the other visa category that is not points tested, the Preferential Family category, changes from -0.357 to -0.394 to -0.265 . In wave one, where the interviews were conducted 6 months after the immigrants had arrived in Australia, all coefficients on the visa category variables were significant at the 10 percent level or better even when other variables were held constant. In wave two, where the immigrants had been in Australia for around $1 \frac{1}{2}$ years, three of the four visa category variables were significant. But by wave three, where the immigrants had been in Australia for $3 \frac{1}{2}$ years, none of the visa category variables were significant. In the language of the screening literature, this suggests that if visa category is a screen, it is of the weak as compared to strong variety when other variables are the same. ${ }^{20}$ Yet some of these other variables that are taken into account in this statistical analysis enter directly into the determinants of visa category.

In comparison to the visa category variables, the impact of the age at migration variable intensifies with duration of residence in Australia. One of the factors that age at migration captures is efficiency in learning languages. Thus, an older age at migration appears to be associated with a lesser efficiency in dominant language acquisition skills, and this impact intensifies with duration of residence in Australia, as reflected in the change in the age at migration coefficients, from -0.015 to -0.030 to -0.045 with a longer duration of residence in Australia.

The estimated impacts associated with the education variable are reasonably stable across the waves of data. In other words, the English speaking skills of the

\footnotetext{
${ }^{20}$ Psacharopoulos (1979) proposes that where the effects of a screen persist over time then the screen is a strong one, while where the effects dissipate then the screen is a weak one.
} 
better educated that were present at the time of entry persist with duration in Australia. They do not intensify. This suggests that the advantages of the better educated may be due to the learning of English prior to migration (perhaps in the schools system) rather than being due to a greater efficiency in English skills development post arrival.

Finally, it is noted that there is little difference between the gender effects in the first two waves of data. However, the negative effect of being female on English speaking skills is much more pronounced (and stronger statistically) in wave three, where the immigrants had been in Australia for approximately $3 \frac{1 / 2}{2}$ years. This is exactly the change that would be expected where females have lower labor supply and less labor market attachments, and the learning of English occurs on the job or, if investments in language are made, for labor market activities.

Tables 6 and 7 present selected results for the analyses conducted into the links between visa category and English reading and writing skills. It is apparent from the cross-tabulations discussed in Section IV that the recent settler arrivals in Australia are more likely to be able to read English than they are to either speak or write English. The mean proficiency rates at the time of the first interview were 60.8 percent for reading skills and 53.5 percent for writing skills. At the second interview the proficiency rates were 69.1 and 59.3 percent, respectively, while they were 72.6 and 62.6 percent at the third interview.

Tables 6 and 7 have three distinct patterns. First, there is a clear distinction between the reading and writing skills of immigrants who entered Australian under points-tested visa categories and those who were not points-tested for entry into Australia. English language proficiency is one of a number of factors taken into account when assessing potential immigrants in the Concessional Family, Business 
Skills/ENS and Independent categories, and the results therefore show that these English language requirements are effective. ${ }^{21}$ Second, the impact of visa category on English reading and writing skills is muted by the inclusion of variables for the immigrants' characteristics in the estimating equation. This finding is similar to that discussed above for English-speaking skills. Third, in contrast to the findings for English-speaking skills, the impact of visa category on English reading and writing skills does not diminish with duration of residence in Australia. Thus, with respect to reading and writing skills, which are typically developed after speaking skills ${ }^{22}$, the impact of visa category persists, at least for the first $3 \frac{1}{2}$ years of residence in Australia covered in this analysis.

Finally, it is noted that the effect of educational attainment on English reading and writing skills is quite stable at the different durations of residence in Australia, and the effect of age at migration tends to intensify the longer the immigrant resides in Australia, although the pattern is irregular. It is also observed that there is no clear pattern to the gender effects in the analysis of English reading and writing skills. In the study of English-speaking skills it was found that the lower proficiency among women intensifies with duration of residence in Australia, a trend that was argued to be associated with females' lesser role, on average, in the labor market, and Englishspeaking skills being learned on-the-job or in expectation of labor market activities. The different pattern established for reading and writing skills in comparison to speaking skills suggests that speaking skills are more relevant to the type of work undertaken by women. Chiswick, Lee and Miller (2002a) show that female recent

\footnotetext{
${ }^{21}$ Since the time of the survey the English language requirements have been tightened. Currently all applicants for skills based visas must be proficient in English (writing, reading, listening and speaking) at the vocational level.

In Chiswick (1991), for example, uses English-speaking skills as an explanatory variable in models of English-reading skills.
} 
arrivals are more likely than male recent arrivals to be employed in the "contact" occupations of Salespersons, Clerks and Para-professionals.

\section{Summary and Conclusions}

This paper is concerned with the determinants of English language proficiency among immigrants in Australia, with an emphasis on the role of the Principal Applicant's visa category. The data are from the Longitudinal Survey of Immigrants to Australia which surveyed in three waves Principal Applicants who received their visa prior to immigrating. The language data are self-reported responses to questions on proficiency in speaking, reading, and writing English. The data are for persons age 15 to 64 years at entry who are not from the English-speaking developed countries.

Cross-tabulations reveal that for each of the language skills there is a relation between proficiency and visa category. In particular, economic migrants and skillstested immigrants have a greater proficiency in all three dimensions of English than do other immigrants. Proficiency is greatest under the Independent and Business Skills categories, next under the Concessional Family category (which is partially skills tested), followed by the Preferential Family group (not skills tested), with refugees (Humanitarian visas) having the lowest proficiency in English. This ranking persists in multivariate analysis, even when other variables are the same. The differences in speaking proficiency by visa category diminish with duration in Australia and virtually disappear by wave three, $31 / 2$ years after immigration.

A behavioral model of immigrant destination language proficiency is presented basted on economic incentives, exposure and efficiency factors, and relevant explanatory variables are identified. When they are added to the multivariate analysis with the visa variables, the equation's explanatory power increases. When the 
English-speaking variable is treated as dichotomous, random assignment would give a prediction success rate of about 50 percent, with the visa variables alone the prediction success rate is 66.3 percent, but with variables added for the model of immigrant language acquisition it jumps to 79.0 percent. That is, these variables explain about 40 percent of the prediction success not explained by the visa categories. When the visa categories are deleted the prediction success rate falls by only 0.6 percentage points to 78.4 percent. Thus, the variables that in part determine the number of points under Australia's skills based points system for immigration are the primary determinants of immigrant language skill, and once they are held constant, visa category, per se, provides very little additional explanatory power.

Similar findings hold for reading and writing skills, except that the effect of visa category on language skills does not diminish with duration in Australia up to wave three ( $3 \frac{1}{2}$ years after immigration).

In those longitudinal data, the positive effect of a younger age at migration on English language proficiency increases with the length of time a cohort has been in Australia, and the gender gap (lower proficiency among women) grows with time in the country. The positive effect of education on proficiency does not appear to vary with duration.

In summary, visa category appears to be a weak screen for English-speaking skills as its effects diminish over time, but a strong screen for the two dimensions of literacy. Some of the fundamental determinants of proficiency become more important the longer a cohort is in Australia, such as age at migration and gender. This suggests that it takes time for certain efficiency variables (e.g., age at migration) and economic incentives (e.g., labor market attachment) to have their effects on immigrant destination language proficiency. 
TABLE 1: English Speaking Skills by Visa Category, 15-64 Year Old Males and Females from non-English Speaking Countries

\begin{tabular}{|c|c|c|c|c|c|c|}
\hline \multirow{2}{*}{$\begin{array}{l}\text { English } \\
\text { Speaking } \\
\text { Skill } \\
\text { Level }\end{array}$} & \multicolumn{5}{|c|}{ Visa Category } & \multirow[b]{2}{*}{$\begin{array}{c}\% \text { of } \\
\text { Population } \\
\text { (d) }\end{array}$} \\
\hline & Independent & $\begin{array}{c}\text { Business } \\
\text { Skills/ENS }^{(\mathrm{a})} \\
\end{array}$ & $\begin{array}{c}\text { Concessional } \\
\text { Family } \\
\end{array}$ & $\begin{array}{c}\text { Preferential } \\
\text { Family } \\
\end{array}$ & $\begin{array}{c}\text { Humanitarian } \\
\text { (Refugee) }\end{array}$ & \\
\hline $\begin{array}{l}\text { English } \\
\text { best }^{(\mathrm{b})}\end{array}$ & 22.10 & 18.83 & 20.54 & 10.88 & 0.57 & 11.71 \\
\hline \multicolumn{7}{|c|}{ Another language spoken best and English spoken: } \\
\hline Very well & 28.00 & 21.57 & 17.40 & 12.01 & 4.05 & 13.69 \\
\hline Well & 41.68 & 27.12 & 32.46 & 26.27 & 17.50 & 27.54 \\
\hline Not well & 8.10 & 25.04 & 25.81 & 34.66 & 55.90 & 33.48 \\
\hline Not at all & 0.12 & 7.44 & 3.79 & 16.18 & 21.98 & 13.59 \\
\hline $\operatorname{Total}^{(\mathrm{c}),(\mathrm{d})}$ & 100.00 & 100.00 & 100.00 & 100.00 & 100.00 & 100.00 \\
\hline $\begin{array}{l}\% \text { of } \\
\text { Population }\end{array}$ & 15.07 & 2.75 & 7.79 & 56.62 & 17.76 & 100.00 \\
\hline $\begin{array}{l}\text { (a) ENS denc } \\
\text { (b) The best } 1 \\
\text { (c) The total } \\
\text { reflect a pop } \\
\text { (d) Totals ma }\end{array}$ & $\begin{array}{l}\text { anguage spoken } \\
\text { number of unw } \\
\text { ulation of } 5721 \\
\text { y not sum to } 10\end{array}$ & $\begin{array}{l}\text { omination Schen } \\
\text {; includes those } \\
\text { eighted cases is } \\
\text { due to rounding }\end{array}$ & $\begin{array}{l}\text { ne. } \\
\text { who speak Engli } \\
\text { 4330. These dat } \\
\end{array}$ & $\begin{array}{l}\text { only. } \\
\text { re weighted }\end{array}$ & ing sample weig & hts to \\
\hline
\end{tabular}


TABLE 2: English Reading Skills by Visa Category, 15-64 Year Old Males and Females from non-English Speaking Countries

\begin{tabular}{|c|c|c|c|c|c|c|}
\hline \multirow{2}{*}{$\begin{array}{l}\text { English } \\
\text { Reading } \\
\text { Skill } \\
\text { Level } \\
\end{array}$} & \multicolumn{5}{|c|}{ Visa Category } & \multirow[b]{2}{*}{$\begin{array}{c}\% \text { of } \\
\text { Population }^{(\mathrm{d})}\end{array}$} \\
\hline & Independent & $\begin{array}{c}\text { Business } \\
\text { Skills/ENS }^{(\mathrm{n})} \\
\end{array}$ & $\begin{array}{c}\text { Concessional } \\
\text { Family }\end{array}$ & $\begin{array}{c}\text { Preferential } \\
\text { Family }\end{array}$ & $\begin{array}{c}\text { Humanitarian } \\
\text { (Refugee) }\end{array}$ & \\
\hline $\begin{array}{l}\text { English } \\
\text { best }^{(\mathrm{b})}\end{array}$ & 22.10 & 18.83 & 20.54 & 10.88 & 0.57 & 11.71 \\
\hline \multicolumn{7}{|c|}{ Speaks another language and reads English: } \\
\hline Very well & 45.56 & 27.85 & 34.18 & 21.15 & 8.04 & 23.70 \\
\hline Well & 28.11 & 28.81 & 27.06 & 27.94 & 27.50 & 27.84 \\
\hline Not well & 4.11 & 15.90 & 13.80 & 23.02 & 36.52 & 21.65 \\
\hline Not at all & 0.00 & 1.17 & 0.63 & 0.83 & 5.39 & 1.51 \\
\hline $\begin{array}{l}\text { Do not } \\
\text { SPEAK } \\
\text { English at } \\
\text { all }\end{array}$ & 0.12 & 7.44 & 3.79 & 16.18 & 21.98 & 13.59 \\
\hline Total $^{(\mathrm{c}),(\mathrm{d})}$ & 100.00 & 100.00 & 100.00 & 100.00 & 100.00 & 100.00 \\
\hline $\begin{array}{l}\% \text { of } \\
\text { Population }\end{array}$ & 15.07 & 2.75 & 7.79 & 56.62 & 17.76 & 100.00 \\
\hline
\end{tabular}

\footnotetext{
(a) ENS denotes Employer Nomination Scheme.

(b) The best language spoken; includes those who speak English only.

(c) The total number of unweighted cases is 4330 . These data are weighted using sample weights to reflect a population of 57211 .

(d) Totals may not sum to 100 due to rounding.

Source: Longitudinal Survey of Immigrants to Australia (Wave One).
} 
TABLE 3: English Writing Skills by Visa Category, 15-64 Year Old Males and Females from non-English Speaking Countries

\begin{tabular}{|c|c|c|c|c|c|c|}
\hline \multirow{2}{*}{$\begin{array}{l}\text { English } \\
\text { Writing } \\
\text { Skill } \\
\text { Level }\end{array}$} & \multicolumn{5}{|c|}{ Visa Category } & \multirow[b]{2}{*}{$\begin{array}{c}\% \text { of } \\
\text { Population }^{\text {(d }}\end{array}$} \\
\hline & Independent & $\begin{array}{c}\text { Business } \\
\text { Skills/ENS } \\
\end{array}$ & $\begin{array}{c}\text { Concessional } \\
\text { Family }\end{array}$ & $\begin{array}{c}\text { Preferential } \\
\text { Family }\end{array}$ & $\begin{array}{c}\text { Humanitarian } \\
\text { (Refugee) }\end{array}$ & \\
\hline $\begin{array}{l}\text { English } \\
\text { best }^{\text {(b) }}\end{array}$ & 22.10 & 18.83 & 20.54 & 10.88 & 0.57 & 11.71 \\
\hline \multicolumn{7}{|c|}{ Speaks another language and writes English: } \\
\hline Very well & 33.22 & 22.92 & 22.57 & 12.93 & 4.61 & 15.54 \\
\hline Well & 35.89 & 24.50 & 30.96 & 28.42 & 19.77 & 28.66 \\
\hline Not well & 8.46 & 24.81 & 19.86 & 27.88 & 44.56 & 27.21 \\
\hline Not at all & 0.19 & 1.50 & 2.28 & 2.71 & 8.51 & 3.29 \\
\hline $\begin{array}{l}\text { Do not } \\
\text { SPEAK } \\
\text { English at } \\
\text { all }\end{array}$ & 0.12 & 7.44 & 3.79 & 16.18 & 21.98 & 13.59 \\
\hline $\operatorname{Total}^{(\mathrm{c}),(\mathrm{d})}$ & 100.00 & 100.00 & 100.00 & 100.00 & 100.00 & 100.00 \\
\hline $\begin{array}{l}\% \text { of } \\
\text { Population }\end{array}$ & 15.07 & 2.75 & 7.79 & 56.62 & 17.76 & 100.00 \\
\hline
\end{tabular}

${ }^{\text {(a) }}$ ENS denotes Employer Nomination Scheme.

(b) The best language spoken; includes those who speak English only.

(c) The total number of unweighted cases is 4330 . These data are weighted using sample weights to reflect a population of 57211 .

(d) Totals may not sum to 100 due to rounding.

Source: Longitudinal Survey of Immigrants to Australia (Wave One). 
TABLE 4: Probit Models of English Speaking Skills, 15-64 Year Old Males and Females from Non-English Speaking Countries

\begin{tabular}{|c|c|c|c|}
\hline Variable & $(1)$ & $(2)$ & (3) \\
\hline Constant & $\begin{array}{c}1.352 \\
(17.26)\end{array}$ & $\begin{array}{l}-0.256 \\
(0.68)\end{array}$ & $\begin{array}{l}-0.935 \\
(2.60)\end{array}$ \\
\hline $\begin{array}{l}\text { Visa Category } \\
\text { Humanitarian } \\
\text { (Refugee) }\end{array}$ & $\begin{array}{c}-2.210 \\
(22.74)\end{array}$ & $\begin{array}{l}-0.796 \\
(6.62)\end{array}$ & (a) \\
\hline $\begin{array}{l}\text { Preferential } \\
\text { Family }\end{array}$ & $\begin{array}{c}-1.450 \\
(17.38)\end{array}$ & $\begin{array}{l}-0.357 \\
(2.57)\end{array}$ & (a) \\
\hline $\begin{array}{l}\text { Concessional } \\
\text { Family }\end{array}$ & $\begin{array}{l}-0.884 \\
(7.98)\end{array}$ & $\begin{array}{r}-0.465 \\
(3.52)\end{array}$ & (a) \\
\hline $\begin{array}{l}\text { Business } \\
\text { Skills/ENS }\end{array}$ & $\begin{array}{l}-0.883 \\
(5.54)\end{array}$ & $\begin{array}{r}-0.355 \\
(1.81)\end{array}$ & (a) \\
\hline Age at migration & (a) & $\begin{array}{r}-0.015 \\
(5.07)\end{array}$ & $\begin{array}{l}-0.018 \\
(6.05)\end{array}$ \\
\hline Education & (a) & $\begin{array}{c}0.182 \\
(17.87)\end{array}$ & $\begin{array}{c}0.194 \\
(19.85)\end{array}$ \\
\hline Female & (a) & $\begin{array}{r}-0.164 \\
(2.68)\end{array}$ & $\begin{array}{l}-0.179 \\
(2.98)\end{array}$ \\
\hline $\begin{array}{l}\text { Former British } \\
\text { colony }\end{array}$ & (a) & $\begin{array}{c}1.369 \\
(16.88)\end{array}$ & $\begin{array}{c}1.502 \\
(19.26)\end{array}$ \\
\hline $\begin{array}{l}\text { Cross country/culture } \\
\text { contact in former } \\
\text { home country }\end{array}$ & (a) & $\begin{array}{l}0.187 \\
(3.24)\end{array}$ & $\begin{array}{l}0.193 \\
(3.40)\end{array}$ \\
\hline $\begin{array}{l}\text { Previously visited } \\
\text { Australia }\end{array}$ & (a) & $\begin{array}{l}0.608 \\
(8.98)\end{array}$ & $\begin{array}{c}0.697 \\
(10.67)\end{array}$ \\
\hline $\begin{array}{l}\text { Main reason for choosing State settled } \\
\text { was Family/Friends }\end{array}$ & (a) & $\begin{array}{l}-0.176 \\
(2.12)\end{array}$ & $\begin{array}{l}-0.222 \\
(2.86)\end{array}$ \\
\hline Contact with ethnic agencies & (a) & $\begin{array}{l}-0.066 \\
(1.03)\end{array}$ & $\begin{array}{l}-0.104 \\
(1.67)\end{array}$ \\
\hline Expect to leave Australia & (a) & $\begin{array}{r}-0.375 \\
(2.89)\end{array}$ & $\begin{array}{l}-0.387 \\
(3.05)\end{array}$ \\
\hline Birthplace concentration & (a) & $\begin{array}{c}-0.008 \\
(1.64)\end{array}$ & $\begin{array}{r}-0.009 \\
(1.16)\end{array}$ \\
\hline Distance $/ 1000$ & (a) & $\begin{array}{c}-0.086 \\
(1.31)\end{array}$ & $\begin{array}{l}-0.047 \\
(0.73)\end{array}$ \\
\hline
\end{tabular}


Distance $^{2} / 1 \mathrm{~m}$.

Linguistic distance

Family Structure

MUS $^{(\mathrm{c})}$

$\mathrm{OS}^{(\mathrm{d})}$

$\mathrm{KIDS}^{(\mathrm{c})}$

$\mathrm{MUR}^{(1)}$

$\mathrm{OR}^{(\mathrm{g})}$

$\chi^{2}$

Prediction success

rate (\%) (a)

0.004

0.002

(1.42)

(0.76)

(a)

$-1.751$

$-1.767$

(6.51)

(6.61)

(a)

$-0.242$

$-0.211$

(a)

$-0.285$

$-0.170$

(2.78)

(a)

$-0.165$

$-0.203$

(2.41)

(a)

$-0.094$

$-0.179$

(0.61)

(a)

$-0.288$

$-0.317$

(4.49)

700.84

1961.14

1911.75

66.27

78.96

78.41

Sample size $\mathrm{e}^{(\mathrm{h})}$

Note: Numbers in parentheses are ' $t$ ' statistics.

(a) Variable not entered.

(b) ENS denotes Employer Nomination Scheme.

(c) Whether a spouse who was part of the migrating unit is present in the household.

(d) Whether a spouse who was not part of the migrating unit is present in the household.

(e) Whether children in the household.

${ }^{(1)}$ Whether other relatives who gained approval to migrate to Australia as part of the Principal Applicant's migration application are present in the household.

(b) Whether other relatives are present in the household.

(h) The total number of cases is 3418 . These data are weighted using sample weights to reflect a population of 48463 .

The benchmark group defined by the omitted categorical variables is male immigrants from migrating units that entered Australia under Independent visas, did not report cross country/culture in the former home country, were not from a former British colony, did not visit Australia prior to migrating, chose their initial State settled for reasons other than Family/Friends, did not have post-immigration contact with ethnic agencies and do not expect to leave Australia.

Source: Longitudinal Survey of Immigrants to Australia (Wave One). 
TABLE 5: Probit Models of English Speaking Skills, 15-64 Year Old Males and Females from Non-English Speaking Countries, Selected Variables

\begin{tabular}{|c|c|c|c|c|c|c|}
\hline & \multicolumn{3}{|c|}{ Wave Two } & \multicolumn{3}{|c|}{ Wave Three } \\
\hline Variable & (1) & (2) & (3) & (1) & (2) & (3) \\
\hline Constant & $\begin{array}{c}1.528 \\
(16.37)\end{array}$ & $\begin{array}{l}-0.094 \\
(0.22)\end{array}$ & $\begin{array}{l}-0.531 \\
(1.33)\end{array}$ & $\begin{array}{c}1.581 \\
(14.60)\end{array}$ & $\begin{array}{l}1.179 \\
(2.49)\end{array}$ & $\begin{array}{l}0.939 \\
(2.09)\end{array}$ \\
\hline $\begin{array}{l}\text { Visa Category } \\
\text { Humanitarian } \\
\text { (Refugee) }\end{array}$ & $\begin{array}{l}-1.836 \\
(16.99)\end{array}$ & $\begin{array}{l}-0.407 \\
(3.03)\end{array}$ & (a) & $\begin{array}{l}-1.525 \\
(12.35)\end{array}$ & $\begin{array}{l}-0.179 \\
(1.16)\end{array}$ & (a) \\
\hline $\begin{array}{l}\text { Preferential } \\
\text { Family }\end{array}$ & $\begin{array}{l}-1.409 \\
(14.32)\end{array}$ & $\begin{array}{l}-0.394 \\
(2.59)\end{array}$ & (a) & $\begin{array}{l}-1.325 \\
(11.66)\end{array}$ & $\begin{array}{l}-0.265 \\
(1.63)\end{array}$ & (a) \\
\hline $\begin{array}{l}\text { Concessional } \\
\text { Family }\end{array}$ & $\begin{array}{l}-0.842 \\
(6.56)\end{array}$ & $\begin{array}{l}-0.361 \\
(2.39)\end{array}$ & (a) & $\begin{array}{l}-0.721 \\
(4.84)\end{array}$ & $\begin{array}{l}-0.159 \\
(0.91)\end{array}$ & (a) \\
\hline $\begin{array}{l}\text { Business } \\
\text { Skills/ENS }\end{array}$ & $\begin{array}{l}-0.868 \\
(4.56)\end{array}$ & $\begin{array}{l}-0.296 \\
(1.23)\end{array}$ & (a) & $\begin{array}{l}-1.052 \\
(5.04)\end{array}$ & $\begin{array}{c}-0.409 \\
(1.56)\end{array}$ & (a) \\
\hline Age at migration & (a) & $\begin{array}{l}-0.030 \\
(9.37)\end{array}$ & $\begin{array}{l}-0.032 \\
(10.18)\end{array}$ & (a) & $\begin{array}{c}-0.045 \\
(11.89)\end{array}$ & $\begin{array}{l}-0.047 \\
(12.46)\end{array}$ \\
\hline Education & (a) & $\begin{array}{c}0.176 \\
(17.13)\end{array}$ & $\begin{array}{c}0.183 \\
(18.50)\end{array}$ & (a) & $\begin{array}{c}0.164 \\
(14.53)\end{array}$ & $\begin{array}{c}0.168 \\
(15.40)\end{array}$ \\
\hline Female & (a) & $\begin{array}{l}-0.098 \\
(1.49)\end{array}$ & $\begin{array}{l}-0.115 \\
(1.77)\end{array}$ & (a) & $\begin{array}{r}-0.305 \\
(4.09)\end{array}$ & $\begin{array}{r}-0.319 \\
(4.34)\end{array}$ \\
\hline$\chi^{2}$ & 276.96 & 1393.37 & 1382.98 & 12.04 & 1016.50 & 1012.56 \\
\hline $\begin{array}{l}\text { Prediction success } \\
\text { rate }(\%)\end{array}$ & 69.08 & 78.77 & 78.70 & 71.62 & 81.87 & 81.95 \\
\hline $\begin{array}{l}\text { Mean proficiency rate } \\
(\%) \\
\text { Sample size } \\
(\mathrm{c})\end{array}$ & & $\begin{array}{l}59.58 \\
2930\end{array}$ & & & $\begin{array}{l}65.52 \\
2410\end{array}$ & \\
\hline
\end{tabular}

Note: Numbers in parentheses are ' $t$ ' statistics. The specifications of the estimating equations denoted (1), (2) and (3) are the same as for Table 4.

(a) Variable not entered.

${ }^{(b)}$ ENS denotes Employer Nomination Scheme.

(c) The total number of cases for the wave 2 analyses is 2930 . These data are weighted using sample weights to reflect a population of 45534. For the wave 3 analyses the total number of cases is 2410 . The wave 3 data are weighted using sample weights to reflect a population of 42545 .

Source: Longitudinal Survey of Immigrants to Australia (Waves Two and Three). 
TABLE 6: Probit Models of English Reading Skills, 15-64 Year Old Males and Females from Non-English Speaking Countries, Selected Variables

\begin{tabular}{|c|c|c|c|c|c|c|}
\hline & \multicolumn{2}{|c|}{ Wave One } & \multicolumn{2}{|c|}{ Wave Two } & \multicolumn{2}{|c|}{ Wave Three } \\
\hline Variable & (1) & (2) & (1) & (2) & (1) & (2) \\
\hline Constant & $\begin{array}{c}1.729 \\
(17.47)\end{array}$ & $\begin{array}{l}-0.830 \\
(2.06)\end{array}$ & $\begin{array}{c}1.986 \\
(15.28)\end{array}$ & $\begin{array}{l}-0.651 \\
(0.76)\end{array}$ & $\begin{array}{c}2.112 \\
(12.93)\end{array}$ & $\begin{array}{l}0.853 \\
(1.55)\end{array}$ \\
\hline $\begin{array}{l}\text { Visa Category } \\
\text { Humanitarian } \\
\text { (Refugee) }\end{array}$ & $\begin{array}{l}-2.193 \\
(19.59)\end{array}$ & $\begin{array}{l}-0.586 \\
(4.26)\end{array}$ & $\begin{array}{l}-1.979 \\
(14.09)\end{array}$ & $\begin{array}{l}-0.686 \\
(3.98)\end{array}$ & $\begin{array}{l}-1.937 \\
(11.13)\end{array}$ & $\begin{array}{l}-0.510 \\
(2.47)\end{array}$ \\
\hline $\begin{array}{l}\text { Preferential } \\
\text { Family }\end{array}$ & $\begin{array}{l}-1.545 \\
(14.98)\end{array}$ & $\begin{array}{l}-0.040 \\
(0.25)\end{array}$ & $\begin{array}{l}-1.600 \\
(11.96)\end{array}$ & $\begin{array}{l}-0.425 \\
(2.26)\end{array}$ & $\begin{array}{l}-1.618 \\
(9.68)\end{array}$ & $\begin{array}{r}-0.604 \\
(2.81)\end{array}$ \\
\hline $\begin{array}{l}\text { Concessional } \\
\text { Family }\end{array}$ & $\begin{array}{l}-0.877 \\
(6.69)\end{array}$ & $\begin{array}{l}-0.338 \\
(2.13)\end{array}$ & $\begin{array}{r}-0.997 \\
(6.15)\end{array}$ & $\begin{array}{l}-0.609 \\
(3.15)\end{array}$ & $\begin{array}{r}-1.034 \\
(5.22)\end{array}$ & $\begin{array}{r}-0.603 \\
(2.62)\end{array}$ \\
\hline $\begin{array}{l}\text { Business } \\
\text { Skills/ENS }\end{array}$ & $\begin{array}{l}-1.072 \\
(6.13)\end{array}$ & $\begin{array}{l}-0.458 \\
(2.09)\end{array}$ & $\begin{array}{r}-1.103 \\
(5.02)\end{array}$ & $\begin{array}{l}-0.449 \\
(1.61)\end{array}$ & $\begin{array}{r}-1.329 \\
(5.11)\end{array}$ & $\begin{array}{l}-0.810 \\
(2.56)\end{array}$ \\
\hline Age at migration & (a) & $\begin{array}{l}-0.020 \\
(6.65)\end{array}$ & (a) & $\begin{array}{l}-0.017 \\
(5.47)\end{array}$ & (a) & $\begin{array}{r}-0.033 \\
(8.43)\end{array}$ \\
\hline Education & (a) & $\begin{array}{c}0.222 \\
(21.05)\end{array}$ & (a) & $\begin{array}{c}0.218 \\
(20.26)\end{array}$ & (a) & $\begin{array}{c}0.194 \\
(16.18)\end{array}$ \\
\hline Female & (a) & $\begin{array}{l}-0.217 \\
(3.45)\end{array}$ & (a) & $\begin{array}{c}-0.079 \\
(1.16)\end{array}$ & (a) & $\begin{array}{l}-0.061 \\
(0.76)\end{array}$ \\
\hline$\chi^{2}$ & 499.81 & 1844.19 & 127.35 & 1163.73 & 252.29 & 833.35 \\
\hline $\begin{array}{l}\text { Prediction success } \\
\text { rate (\%) }\end{array}$ & 70.68 & 80.58 & 73.67 & 82.46 & 77.98 & 85.23 \\
\hline $\begin{array}{l}\text { Mean proficiency } \\
\text { rate }(\%)\end{array}$ & & & & & & \\
\hline Sample size $e^{(\mathrm{c})}$ & & & & & & \\
\hline
\end{tabular}

Note: Numbers in parentheses are ' $t$ ' statistics. The specifications denoted (1) and (2) correspond to the models denoted (1) and (2) in Table 4. Hence model (1) contains only variables for visa category while model (2) also includes age at migration, education, gender, main reason for choosing State settled, the family structure and the behavioral variables that are related to birthplace groups.

${ }^{\text {(a) }}$ Variable not entered.

(b) ENS denotes Employer Nomination Scheme.

(c) The total number of cases for the wave 1 analyses is 3414 . These data are weighted using sample weights to reflect a population of 48495 . For the waves 2 and 3 analyses the total number of cases are 2931 and 2343, respectively. The waves 2 and 3 data are weighted using sample weights to reflect a population of 45565 and 41263 , respectively.

Source: Longitudinal Survey of Immigrants to Australia (Waves One, Two and Three). 
TABLE 7: Probit Models of English Writing Skills, 15-64 Year Old Males and Females from Non-English Speaking Countries, Selected Estimates

\begin{tabular}{|c|c|c|c|c|c|c|}
\hline & \multicolumn{2}{|c|}{ Wave One } & \multicolumn{2}{|c|}{ Wave Two } & \multicolumn{2}{|c|}{ Wave Three } \\
\hline Variable & (1) & (2) & $(1)$ & $(2)$ & (1) & (2) \\
\hline Constant & $\begin{array}{c}1.337 \\
(17.20)\end{array}$ & $\begin{array}{l}-0.959 \\
(2.51)\end{array}$ & $\begin{array}{c}1.529 \\
(16.36)\end{array}$ & $\begin{array}{l}-0.054 \\
(0.13)\end{array}$ & $\begin{array}{c}1.596 \\
(14.59)\end{array}$ & $\begin{array}{r}-0.223 \\
(0.49)\end{array}$ \\
\hline Visa Category & & & & & & \\
\hline $\begin{array}{l}\text { Humanitarian } \\
\text { (Refugee) }\end{array}$ & $\begin{array}{l}-2.096 \\
(21.90)\end{array}$ & $\begin{array}{r}-0.533 \\
(4.40)\end{array}$ & $\begin{array}{l}-1.875 \\
(17.32)\end{array}$ & $\begin{array}{l}-0.588 \\
(4.38)\end{array}$ & $\begin{array}{l}-1.878 \\
(15.03)\end{array}$ & $\begin{array}{l}-0.632 \\
(4.21)\end{array}$ \\
\hline $\begin{array}{l}\text { Preferential } \\
\text { Family }\end{array}$ & $\begin{array}{l}-1.331 \\
(16.06)\end{array}$ & $\begin{array}{l}-0.209 \\
(1.46)\end{array}$ & $\begin{array}{l}-1.413 \\
(14.35)\end{array}$ & $\begin{array}{l}-0.660 \\
(4.38)\end{array}$ & $\begin{array}{l}-1.345 \\
(11.73)\end{array}$ & $\begin{array}{l}-0.260 \\
(1.64)\end{array}$ \\
\hline $\begin{array}{l}\text { Concessional } \\
\text { Family }\end{array}$ & $\begin{array}{l}-0.761 \\
(6.83)\end{array}$ & $\begin{array}{l}-0.315 \\
(2.31)\end{array}$ & $\begin{array}{l}-0.819 \\
(6.36)\end{array}$ & $\begin{array}{l}-0.442 \\
(2.89)\end{array}$ & $\begin{array}{l}-0.885 \\
(6.04)\end{array}$ & $\begin{array}{l}-0.514 \\
(3.04)\end{array}$ \\
\hline $\begin{array}{l}\text { Business } \\
\text { Skills/ENS }\end{array}$ & $\begin{array}{l}-0.914 \\
(5.78)\end{array}$ & $\begin{array}{r}-0.217 \\
(1.11)\end{array}$ & $\begin{array}{l}-0.901 \\
(4.75)\end{array}$ & $\begin{array}{l}-0.272 \\
(1.17)\end{array}$ & $\begin{array}{l}-1.098 \\
(5.27)\end{array}$ & $\begin{array}{r}-0.529 \\
(2.10)\end{array}$ \\
\hline Age at migration & (a) & $\begin{array}{l}-0.023 \\
(7.33)\end{array}$ & (n) & $\begin{array}{l}-0.016 \\
(4.94)\end{array}$ & (a) & $\begin{array}{r}-0.030 \\
(8.18)\end{array}$ \\
\hline Education & (a) & $\begin{array}{c}0.208 \\
(19.51)\end{array}$ & (a) & $\begin{array}{c}0.184 \\
(17.70)\end{array}$ & (n) & $\begin{array}{c}0.191 \\
(16.66)\end{array}$ \\
\hline Female & (a) & $\begin{array}{l}-0.096 \\
(1.58)\end{array}$ & (a) & $\begin{array}{l}0.057 \\
(0.89)\end{array}$ & (a) & $\begin{array}{l}-0.105 \\
(1.47)\end{array}$ \\
\hline$\chi^{2}$ & 619.01 & 1946.69 & 324.03 & 1390.48 & 222.64 & 1051.16 \\
\hline $\begin{array}{l}\text { Prediction success } \\
\text { rate }(\%)\end{array}$ & 65.24 & 78.09 & 68.20 & 77.41 & 69.25 & 78.49 \\
\hline $\begin{array}{l}\text { Mean proficiency } \\
\text { rate }(\%)\end{array}$ & & & & & & \\
\hline Sample size $\mathrm{e}^{(\mathrm{c})}$ & & & & & & \\
\hline
\end{tabular}

Note: Numbers in parentheses are ' $t$ ' statistics. The specifications denoted (1) and (2) correspond to the models denoted (1) and (2) in Table 4. Hence model (1) also contains only variables for visa category while model (2) includes age at migration, education, gender, main reason for choosing State settled, the family structure and the behavioral variables that are related to birthplace groups.

(a) Variable not entered.

(b) ENS denotes Employer Nomination Scheme.

(c) The total number of cases for the wave 1 analyses is 3418 . These data are weighted using sample weights to reflect a population of 48463 . For the waves 2 and 3 analyses the total number of cases are 2918 and 2413, respectively. The waves 2 and 3 data are weighted using sample weights to reflect a population of 41156 and 42616 , respectively.

Source: Longitudinal Survey of Immigrants to Australia (Waves One, Two and Three). 


\section{REFERENCES}

Amemiya, Takashi (1981). "Qualitative Response Models: A Survey", Joumal of Economic Literature, Vol.19, pp.1483-1536.

Chiswick, Barry R. (1991). "Speaking, Reading, and Earnings Among Low-skilled Immigrants", Joumal of Labor Economics, Vol. 9, No. 2, pp. 149-170.

Chiswick, Barry R. (1998). "Hebrew Language Usage: Determinants and Effects on Earnings among Immigrants in Israel", Journal of Population Economics, Vol. 11 , No. 2, pp. 253-271.

Chiswick, Barry R. and Paul W. Miller (1992a). "Language in the Labor Market: The Immigrant Experience in Canada and the United States", in Barry R. Chiswick (ed.) Immigration, Language and Ethnic Issues: Canada and the United States, Washington, DC: American Enterprise Institute, pp. 229-296.

Chiswick, Barry R. and Paul W. Miller (1992b). Post-immigration Qualifications in Australia: Determinants and Consequences, Canberra: Australian Govenrment Publishing Service.

Chiswick, Barry R. and Paul W. Miller (1994). "Language Choice Among Immigrants in a Multi-Lingual Destination", Journal of Population Economics, Vol. 7, No. 2, pp. 119-131.

Chiswick, Barry R. and Paul W. Miller (1995). "The Endogeneity Between Language and Earnings: International Analyses", Journal of Labor Economics, Vol. 13, No. 2, pp. 246-288.

Chiswick, Barry R. and Paul W. Miller (1996). "Ethnic Networks and Language Proficiency Among Immigrants", Journal of Population Economics, Vol. 9, pp. 19-35.

Chiswick, Barry R. and Paul W. Miller (1998). "English Language Fluency Among Immigrants in the United States", Research in Labor Economics, Vol. 17, pp. 151-200.

Chiswick, Barry R. and Paul W. Miller (1999). "Immigration, Language and Multiculturalism in Australia", Australian Economic Review, Vol. 32, No. 4, pp. 369-385.

Chiswick, Barry R. and Paul W. Miller (2001). "A Model of Destination Language Acquisition: Application to Male Immigrants in Canada", Demography Vol. 38, No. 3, pp. 391-409.

Chiswick, Barry R., Yew Liang Lee and Paul W. Miller (2002a). "Immigrant Occupational Attainment and the Labor Market Adjustment of Males and Females in Australia", photocopied, Department of Economics, The University of Western Australia. 
Chiswick, Barry R., Yew Liang Lee and Paul W. Miller (2002b). "Family Matters: The Role of the Family in Immigrants' Destination Language Acquisition", photocopied, Department of Economics, The University of Western Australia.

Department of Immigration and Multicultural Affairs (DIMA) (1997). Australian Immigration: Consolidated Statistics, No. 19, 1995-1996, Canberra: DIMA.

Dustmann, Christian (1994). "Speaking Fluency, Writing Fluency and Earnings of Migrants", Journal of Population Economics, Vol. 7, No. 2, pp. 226-236.

Espenshade, Thomas J. and Haishan Fu (1997). "An Analysis of English Language Proficiency Among U.S. Immigrants," American Sociological Review, Vol. 62, April, pp. 288-305.

Fitzpatrick, Gary L. and Marilyn J. Modlin (1986). Direct-line Distances: International Edition, Metuchen, NJ: The Scarecrow Press Inc.

Hart-Gonzalez, Lucinda and Stephanie Lindemann (1993). "Expected Achievement in Speaking Proficiency, 1993," School of Language Studies, Foreign Services Institute, Department of State, mimeo.

Long, Michael H. (1990). "Maturational Constraints on Language Development", Studies in Second Language Acquisition, Vol. 12, No. 3, pp. 251-285.

Miller, Paul W. (1999). "Immigration Policy and Immigrant Quality: The Australian Points System", American Economic Review, Papers and Proceedings, Vol. 89, No. 2, pp. 192-197.

Murphy, Jill (1997). Initial Location Decisions of Immigrants, Canberra: Department of Immigration and Multicultural Affairs.

Osborne, David, (1999). "Effects of Sample Loss", in Adriana VandenHeuvel and Mark Wooden New Settlers Have Their Say: How Immigrants Fare Over the Early Years of Settlement, Canberra: Department of Immigration and Multicultural Affairs.

Psacharopoulos, George (1979). "On the Weak Versus the Strong Version of the Screening Hypothesis", Economics Letters, Vol. 4, pp. 181-185.

Service, Elisabet and Fergus I.M. Craik (1993). "Differences Between Young and Older Adults in Learning a Foreign Vocabulary", Joumal of Memory and Language, Vol. 32, pp. 608-623.

Wooden, Mark (1990). Migrant Labor Market Status, Canberra: Australian Government Publishing Service. 


\section{APPENDIX A \\ DEFINITIONS OF VARIABLES}

The study is based on the Longitudinal Survey of Immigrants to Australia, a sample of Principal Applicant immigrants who arrived in Australia as offshore visaed immigrants in the two-year period of September 1993 to August 1995. The variables used in the statistical analysis are described below. For the statistical analyses, the relevant population is immigrants aged 15-64 years from the main English-speaking countries.

\section{Dependent Variables:}

English Speaking Skills: Five levels of English speaking skills are distinguished. They are: (i) English best (or English only); Speaks a language other than English best and speaks English: (ii) Very well; (iii) Well; (iv) Not well; (v) Not at all. In some analyses the first three categories (denoted "proficient") are distinguished from the remaining categories (denoted "not proficient").

English Reading Skills: Five levels of English reading skills are distinguished. They are: (i) English best (or English only); Speaks a language other than English best and reads English: (ii) Very well; (iii) Well; (iv) Not well; (v) Not at all, or does not speak English at all. ${ }^{23}$ In some analyses the first three categories (denoted "proficient") are distinguished from the remaining categories (denoted "not proficient").

English Writing Skills: Five levels of English writing skills are distinguished. They are: (i) English best (or English only); Speaks a language other than English best and writes English: (ii) Very well; (iii) Well; (iv) Not well; (v) Not at all, or does not speak English at all. ${ }^{24}$ In some analyses the first three categories (denoted "proficient") are distinguished from the remaining categories (denoted "not proficient").

\section{Independent Variables:}

Age: This is a continuous variable that measures the individual's age. The analysis is restricted to immigrants aged 15 to 64 years.

Educational Attainment: The continuous "Years of Education" variable was created by assigning years of full-time equivalent education to each of the nine levels of education available. They are: (i) Higher degree (19.5 years); (ii) Postgraduate diploma (17.5 years); (iii) Bachelor degree (16.5 years); (iv) Technical/professional qualification (15 years); (v) Trade (13 years) ; (vi) 12 or more years of schooling (13 years); (vii) 10-11 years (10.5 years); (viii) 7-9 years (8 years); and (ix) 6 years or less (6 years).

\footnotetext{
${ }^{23}$ Information on English reading skills was not collected where the individual could not speak English at all. It is assumed that these individuals would not be able to read English.

${ }^{24}$ Information on English writing skills was not collected where the individual could not speak English at all. It is assumed that these individuals would not be able to write in English.
} 
Gender: Dichotomous variable equal to unity if female.

Birthplace: Fourteen birthplace regions are distinguished, namely (i) UK and Ireland; (ii) Southern Europe; (iii) Western Europe; (iv) Northern Europe; (v) Eastern Europe; (vi) The USSR and the Baltic States; (vii) The Middle East; (viii) North Africa; (ix) Southeast Asia; (x) Northeast Asia; (xi) Southern Asia; (xii) Northern America; (xiii) South and Central America, including Mexico; (xiv) Caribbean, Central and West Africa, and Southern and East Africa. The analysis is restricted to non-English speaking countries (i.e., immigrants from UK and Ireland, North America and South Africa are excluded). The region of Caribbean, Central and West Africa, and Southern and East Africa has been excluded from the analysis as insufficient immigrants are represented to permit construction of some of the auxiliary regressors employed in the analysis. Southern Europe is used as the benchmark group in the analysis. Note that immigrants from New Zealand are not included in the survey. An additional birthplace dichotomous variable is set equal to unity for birthplaces that are former British colonies.

Culture/Country Contact: Dichotomous variable equal to unity if the immigrant had cross culture/country contact in their former home country.

Visit to Australia: Dichotomous variable equal to unity for those from migrating units where the PA visited Australia prior to migrating.

Reason for Choice of State Settled: Dichotomous variable equal to unity when family and friends were the main reason for choosing the initial State/Territory settled.

Ethnic Agencies Contact: Dichotomous variable equal to unity when the recent arrival had post-immigrant contact with an ethnic organisation, religious organisation, or voluntary welfare agency.

Emigration: Dichotomous variable equal to unity for PAs who expect to return to their former home country or to emigrate to another country.

Birthplace Concentration: The percentage of those in the immigrant's region of residence, measured at the postcode level, born in the same country or region as the immigrant. ${ }^{25}$

Distance: The kilometres between the major city in the immigrant's country of origin and the capital city of the wave one Australian State/Territory of residence. ${ }^{26}$

Linguistic Distance: This variable is constructed from a measure of the difficulty of learning a foreign language for English-speaking Americans. It is based on a set of language scores (LS) measuring achievements in speaking proficiency by English-

\footnotetext{
25 The birthplace concentration data are from the 1991 Australian Census of Population and Housing (see Australian Bureau of Statistics (1993)).

${ }^{26}$ These data are from Fitzpatrick and Modlin's (1986) Direct Line Distances, International Edition.
} 
speaking Americans at the U.S. Department of State, School of Language Studies, reported by Hart-Gonzalez and Lindermann (1993). For the same number of weeks of instruction, a lower score (LS) represents less language facility, and, it is assumed, greater linguistic distance between English and the specific foreign language. For example, Italian is scored at 2.5 (in a range from one to three) and Arabic is scored at 1.5. This methodology assumes symmetry across languages, that is, if a language is difficult for English-speaking Americans to learn, it is equally difficult for native speakers of that language to learn English.

Visa Group: Five visa groups are identified in the analysis, and dichotomous variables are used to represent membership of these. They are: (i) Preferential Family; (ii) Concessional Family; (iii) Business Skills and Employer Nomination; (iv) Independent; and (v) Humanitarian. The benchmark group in the regression analysis is Independent. The Preferential Family category provides for the entry of spouses, fiancés, unmarried dependent children, children for adoption or adopted by Australians while overseas, parents meeting the "balance of family" test, as well as aged dependent, "last remaining", "special need" and orphan child relatives. There is no points test for this category. The Concessional Family category allows for the sponsorship of non-dependent children, parents who do not meet the "balance of family" test, siblings, and nieces and nephews. A points test is applied to this category based mainly on the job-related skills (particularly qualifications), age and Englishlanguage proficiency of the applicant. Business Skills aims to attract people with successful careers in business and who have a genuine and realistic commitment to establishing new businesses or actively participating in existing businesses that will benefit Australia. Applicants are subject to a points test which assess them against their business backgrounds, achievements and skills. The Employer Nomination Scheme is designed to enable Australian employers who are unable to fill vacancies within the Australian labor market or through their own training efforts to recruit skilled workers from overseas. During 1993-95 approximately equal numbers of settlers entered Australian under the Business Skills and Employer Nomination streams (see DIMA (1997). The Independent category emphasises the selection of young, skilled, employable people through a points test based on skill (qualifications and work experience), age, and English proficiency. The Humanitarian program is a flexible program designed to respond to changing international situations. It consists of 3 main categories: Refugee, for those determined as refugees under the United Nations Convention; Special Humanitarian Program for those who suffer severe discrimination amounting to gross violation of human rights; and Special Assistance Category for those who have close links with Australia and who are in situations of discrimination, displacement or hardship. During 1993-95 Refugees comprised around 30 percent, those entering under the Special Humanitarian Program around 25 percent and settlers in the Special Assistance category about 45 percent of the total Humanitarian program (DIMA (1997)).

Family Structure: In the specification where dichotomous variables are used, five variables relating to family structure are distinguished. They are unity: (i) if a spouse who was part of the migrating unit is present in the household (MUS); (ii) if a spouse who was not part of the migrating unit is present in the household (OS); (iii) if there are children in the household (KIDS); (iv) if other relatives who gained approval to migrate to Australia as part of the Principal Applicant's migration application are 
present in the household (MUR); and (v) if other relatives are present in the household (OR).

TABLE A1: Means and Standard Deviations of Variables, 15-64 Year Old Males and Females from Non-English Speaking Countries

\begin{tabular}{|c|c|c|c|c|c|}
\hline Variable & Mean & $\begin{array}{l}\text { Standard } \\
\text { Deviation }\end{array}$ & Variable & Mean & $\begin{array}{l}\text { Standard } \\
\text { Deviation }\end{array}$ \\
\hline $\begin{array}{l}\text { English Speaking } \\
\text { proficiency }\end{array}$ & 0.504 & 0.500 & $\begin{array}{l}\text { Culture/Country } \\
\text { Contact } \\
\text { Visit to Australia }\end{array}$ & $\begin{array}{l}0.632 \\
0.361\end{array}$ & $\begin{array}{l}0.482 \\
0.480\end{array}$ \\
\hline $\begin{array}{l}\text { English Reading } \\
\text { proficiency }\end{array}$ & 0.608 & 0.488 & $\begin{array}{l}\text { Main reason for } \\
\text { choosing State } \\
\text { settled was }\end{array}$ & & \\
\hline & & & $\begin{array}{l}\text { Family/Friends } \\
\text { Ethnic Agencies }\end{array}$ & 0.757 & 0.429 \\
\hline $\begin{array}{l}\text { English Writing } \\
\text { proficiency }\end{array}$ & 0.534 & 0.499 & Contact & 0.271 & 0.445 \\
\hline Age & 33.426 & 9.813 & $\begin{array}{l}\text { Expect to Leave } \\
\text { Australia } \\
\text { Birthplace }\end{array}$ & 0.049 & 0.216 \\
\hline Educational & & & $\begin{array}{l}\text { Concentration } \\
\text { Distance ('000) }\end{array}$ & $\begin{array}{l}1.730 \\
11.348\end{array}$ & $\begin{array}{l}3.543 \\
3.772\end{array}$ \\
\hline Attainment & 14.197 & 3.443 & & & \\
\hline $\begin{array}{l}\text { Female } \\
\text { Birthplace }\end{array}$ & 0.439 & 0.496 & Linguistic Distance & 0.557 & 0.132 \\
\hline $\begin{array}{l}\text { Europe } \\
\text { Northern }\end{array}$ & 0.051 & 0.219 & $\begin{array}{l}\text { Visa Category } \\
\text { Humanitarian }\end{array}$ & & \\
\hline $\begin{array}{l}\text { Europe } \\
\text { Eastern }\end{array}$ & 0.024 & 0.153 & $\begin{array}{l}\text { (Refugee) } \\
\text { Preferential Family }\end{array}$ & $\begin{array}{l}0.174 \\
0.429\end{array}$ & $\begin{array}{l}0.379 \\
0.495\end{array}$ \\
\hline $\begin{array}{l}\text { Europe } \\
\text { Former }\end{array}$ & 0.066 & 0.248 & Concessional & & \\
\hline USSR & 0.056 & 0.231 & Family & 0.164 & 0.371 \\
\hline $\begin{array}{l}\text { The Middle } \\
\text { East }\end{array}$ & 0.153 & 0.360 & $\begin{array}{l}\text { Business } \\
\text { Skills/ENS }\end{array}$ & 0.078 & 0.267 \\
\hline $\begin{array}{l}\text { North Africa } \\
\text { South East }\end{array}$ & 0.030 & 0.170 & & & \\
\hline Asia & 0.208 & 0.406 & Family Structure & & \\
\hline $\begin{array}{l}\text { North East } \\
\text { Asia }\end{array}$ & 0.138 & 0.345 & $\mathrm{MUS}^{(\mathrm{b})}$ & 0.345 & 0.475 \\
\hline South Asia & 0.081 & 0.272 & $O S^{(c)}$ & 0.379 & 0.485 \\
\hline South and & & & $\mathrm{KIDS}^{(\mathrm{d})}$ & 0.396 & 0.489 \\
\hline $\begin{array}{l}\text { Central } \\
\text { America }\end{array}$ & 0.080 & 0.272 & $\operatorname{MUR}^{(e)}$ & 0.023 & 0.148 \\
\hline $\begin{array}{l}\text { Former British } \\
\text { Colony }\end{array}$ & 0.237 & 0.425 & $\mathrm{OR}^{(f)}$ & 0.335 & 0.472 \\
\hline
\end{tabular}

Note: These descriptive statistics are based on the wave one data used in Table 4. The sample size is 3418 , which when weighted using sample weights reflect a population of 48463 .

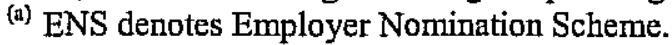


(b) Whether a spouse who was part of the migrating unit is present in the household.

(c) Whether a spouse who was not part of the migrating unit is present in the household.

(d) Whether children in the household.

(e) Whether other relatives who gained approval to migrate to Australia as part of the Principal Applicant's migration application are present in the household.

${ }^{(1)}$ Whether other relatives are present in the household.

Source: Longitudinal Survey of Immigrants to Australia (Wave One). 


\section{APPENDIX B \\ ESTIMATES FOR MALES AND FEMALES SEPARATELY}

TABLE B1: Probit Models of English Speaking Skills, 15-64 Year Old Males and Females from Non-English Speaking Countries

\begin{tabular}{|c|c|c|c|c|}
\hline & \multicolumn{2}{|c|}{ Males } & \multicolumn{2}{|c|}{ Females } \\
\hline Variable & (1) & (2) & (3) & (4) \\
\hline Constant & $\begin{array}{c}1.260 \\
(15.48)\end{array}$ & $\begin{array}{l}-1.379 \\
(2.57)\end{array}$ & $\begin{array}{l}1.726 \\
(8.23)\end{array}$ & $\begin{array}{l}0.849 \\
(1.39)\end{array}$ \\
\hline $\begin{array}{l}\text { Visa Category } \\
\text { Humanitarian } \\
\text { (Refugee) }\end{array}$ & $\begin{array}{l}-2.016 \\
(19.47)\end{array}$ & $\begin{array}{l}-0.759 \\
(5.63)\end{array}$ & $\begin{array}{l}-2.827 \\
(11.75)\end{array}$ & $\begin{array}{l}-1.284 \\
(4.15)\end{array}$ \\
\hline $\begin{array}{l}\text { Preferential } \\
\text { Family }\end{array}$ & $\begin{array}{l}-1.319 \\
(14.03)\end{array}$ & $\begin{array}{l}-0.418 \\
(2.51)\end{array}$ & $\begin{array}{r}-1.843 \\
(8.65)\end{array}$ & $\begin{array}{r}-0.653 \\
(2.09)\end{array}$ \\
\hline $\begin{array}{l}\text { Concessional } \\
\text { Family }\end{array}$ & $\begin{array}{l}-0.880 \\
(7.39)\end{array}$ & $\begin{array}{l}-0.495 \\
(3.47)\end{array}$ & $\begin{array}{l}-1.038 \\
(3.94)\end{array}$ & $\begin{array}{l}-0.731 \\
(2.18)\end{array}$ \\
\hline $\begin{array}{l}\text { Business } \\
\text { Skills/ENS }\end{array}$ & $\begin{array}{l}-0.791 \\
(4.83)\end{array}$ & $\begin{array}{l}-0.176 \\
(0.83)\end{array}$ & $\begin{array}{l}-1.255 \\
(2.91)\end{array}$ & $\begin{array}{l}-0.968 \\
(1.83)\end{array}$ \\
\hline Age at migration & (a) & $\begin{array}{l}-0.015 \\
(3.48)\end{array}$ & (a) & $\begin{array}{l}-0.016 \\
(3.42)\end{array}$ \\
\hline Education & (a) & $\begin{array}{c}0.179 \\
(13.05)\end{array}$ & (a) & $\begin{array}{c}0.183 \\
(11.54)\end{array}$ \\
\hline $\begin{array}{l}\text { Former British } \\
\text { colony }\end{array}$ & (a) & $\begin{array}{c}1.328 \\
(11.50)\end{array}$ & (a) & $\begin{array}{l}1.420 \\
(11.74)\end{array}$ \\
\hline $\begin{array}{l}\text { Cross country/culture } \\
\text { contact in former } \\
\text { home country }\end{array}$ & (a) & $\begin{array}{l}0.190 \\
(2.51)\end{array}$ & (a) & $\begin{array}{l}0.181 \\
(1.99)\end{array}$ \\
\hline $\begin{array}{l}\text { Previously visited } \\
\text { Australia }\end{array}$ & (a) & $\begin{array}{l}0.581 \\
(6.32)\end{array}$ & (a) & $\begin{array}{l}0.652 \\
(6.22)\end{array}$ \\
\hline $\begin{array}{l}\text { Main reason for } \\
\text { choosing State settled } \\
\text { was Family/Friends }\end{array}$ & (a) & $\begin{array}{l}-0.170 \\
(1.80)\end{array}$ & (a) & $\begin{array}{l}-0.266 \\
(1.65)\end{array}$ \\
\hline $\begin{array}{l}\text { Contact with ethnic } \\
\text { organisation }\end{array}$ & (n) & $\begin{array}{l}-0.056 \\
(0.69)\end{array}$ & (a) & $\begin{array}{l}-0.082 \\
(0.79)\end{array}$ \\
\hline $\begin{array}{l}\text { Expect to leave } \\
\text { Australia }\end{array}$ & (u) & $\begin{array}{l}-0.191 \\
(0.98)\end{array}$ & (a) & $\begin{array}{l}-0.475 \\
(2.57)\end{array}$ \\
\hline $\begin{array}{l}\text { Birthplace } \\
\text { concentration }\end{array}$ & (a) & $\begin{array}{l}-0.010 \\
(0.98)\end{array}$ & (a) & $\begin{array}{l}-0.009 \\
(0.80)\end{array}$ \\
\hline Distance/1000 & (a) & $\begin{array}{l}0.111 \\
(1.21)\end{array}$ & (a) & $\begin{array}{l}0.214 \\
(2.17)\end{array}$ \\
\hline
\end{tabular}




\begin{tabular}{|c|c|c|c|c|}
\hline Distance $\frac{2}{1} / 1 \mathrm{~m}$ & (a) & $\begin{array}{l}-0.004 \\
(0.95)\end{array}$ & (a) & $\begin{array}{r}-0.010 \\
(2.10)\end{array}$ \\
\hline Linguistic distance & (a) & $\begin{array}{l}-1.897 \\
(5.36)\end{array}$ & (a) & $\begin{array}{l}-1.686 \\
(3.94)\end{array}$ \\
\hline $\begin{array}{l}\text { Family structure } \\
\text { MUS }^{(\mathrm{c})}\end{array}$ & (a) & $\begin{array}{l}-0.155 \\
(1.26)\end{array}$ & (n) & $\begin{array}{l}-0.339 \\
(1.81)\end{array}$ \\
\hline$O S^{(d)}$ & (a) & $\begin{array}{l}-0.178 \\
(1.25)\end{array}$ & (a) & $\begin{array}{l}-0.484 \\
(2.97)\end{array}$ \\
\hline $\mathrm{KIDS}^{(\mathrm{e})}$ & (a) & $\begin{array}{l}-0.123 \\
(1.31)\end{array}$ & (a) & $\begin{array}{r}-0.220 \\
(2.07)\end{array}$ \\
\hline $\mathrm{MUR}^{(1)}$ & (a) & $\begin{array}{l}0.467 \\
(0.25)\end{array}$ & (a) & $\begin{array}{l}-0.338 \\
(1.29)\end{array}$ \\
\hline $\mathrm{OR}^{(\mathrm{g})}$ & (a) & $\begin{array}{l}0.002 \\
(0.03)\end{array}$ & (a) & $\begin{array}{r}-0.555 \\
(5.46)\end{array}$ \\
\hline$\chi^{2}$ & 473.07 & 1013.34 & 254.70 & 957.17 \\
\hline $\begin{array}{l}\text { Prediction success } \\
\text { rate }(\%)\end{array}$ & 67.54 & 77.59 & 64.64 & 80.25 \\
\hline Sample size ${ }^{(1)}$ & 1919 & 1919 & 1499 & 1499 \\
\hline
\end{tabular}

Note: Numbers in parentheses are ' $\mathrm{t}$ ' statistics.

(a) Variable not entered.

(b) ENS denotes Employer Nomination Scheme.

(c) Whether a spouse who was part of the migrating unit is present in the household.

(d) Whether a spouse who was not part of the migrating unit is present in the household.

(e) Whether children in the household.

(f) Whether other relatives who gained approval to migrate to Australia as part of the Principal Applicant's migration application are present in the household.

(B) Whether other relatives are present in the household.

(b) The total number of males is 1919 . These data are weighted using sample weights to reflect a population of 24086 . The total number of females is 1499 . The data for females are weighted using sample weights to reflect a population of 24377 .

The benchmark group defined by the omitted categorical variables is immigrants from migrating units that entered Australia under Independent visas, did not report cross country/culture in the former home country, were not from a former British colony, did not visit Australia prior to migrating, chose their initial State settled for reasons other than Family/Friends, did not have post-immigration contact with ethnic agencies and do not expect to leave Australia.

Source: Longitudinal Survey of Immigrants to Australia (Wave One). 